\title{
Work First Versus Human Capital Development in Employability
}

\section{Programs}

\author{
Colin Lindsay
}

Published in U-C. Klehe and E. van Hooft (eds) (2014), Oxford handbook of job loss and job search, Oxford University Press: Oxford, published online at:

http://dx.doi.org/10.1093/oxfordhb/9780199764921.013.029

\begin{abstract}
Policymakers across advanced welfare states have prioritized programs to enhance the employability of unemployed people and help them to find and sustain work. In this regard, analysts have drawn attention to the difference between Work First and Human Capital Development (HCD) models. The former seek to direct people to any available job as quickly as possible; the latter seek to improve long-term employability through investments in human capital (typically via education and training). This chapter deploys a framework for comparing Work First- and HCD-oriented approaches to employability, identifying differences in rationales, content, and outcomes. A key conclusion is that policymakers (and indeed researchers) need to adopt a broader, more holistic view of the factors affecting the unemployed. A better understanding can inform the development of programs that combine Work First and HCD elements and address the problems that explain why some people face prolonged periods excluded from the workplace.
\end{abstract}

Keywords: Work First, human capital, employability, activation, active labor market policies, welfare reform 


\section{Introduction}

Policymakers have adopted a range of strategies to promote unemployed job seekers'

employability and help them to find and sustain work. But there are considerable differences in how the "employability gap" encountered by people experiencing unemployment is understood and characterized (McQuaid \& Lindsay, 2005), and this has informed fundamentally different active labor market policies and employability programs. In assessing the content and outcomes of different programs, analysts have suggested that a distinction can be drawn between approaches broadly focused on Work First and Human Capital Development (HCD). The former programs work on the assumption that "any job is better than no job" (Layard, 2003, p. 5), so that services are designed to place people into any available job opportunity as quickly as possible; the latter seek to improve the long-term employability of the unemployed through human capital investment (for example, through training and personal development).

These distinctions matter because, as shown below, Work First- and HCD-type programs tend to produce different outcomes in the immediate and longer terms, contingent on the existing employability of participants, demand in local and national labor markets, and employer needs. There is also considerable debate about whether Work First or HCD programs (and their immediate impacts) are more effective at promoting long-term labor market participation and socioeconomic inclusion (Daguerre \& Etherington, 2009).

Following this introduction, this chapter provides a definition and discussion of Work First and HCD approaches to employability, drawing on US, UK, and other literature, and clearly distinguishing the key features of each model. Drawing on Lindsay et al.'s (2007) framework, the discussion below specifically addresses the key features and differences of Work First and HCD approaches in terms of: their rationale, targets, and priorities; the "intervention model" or 
content of programs; and how they negotiate relationships with individuals and the labor market. The chapter then provides a brief discussion of "what works" in employability strategiesespecially the impact of Work First and HCD models - drawing on evaluation evidence from the United Kingdom, United States, and other countries. The chapter concludes by noting the increasing dominance of Work First in many developed economies/member states of the Organization for Economic Co-operation and Development (OECD) and considers whether these approaches are fit for purpose in an era of high unemployment. The chapter then goes on to identify future directions for research.

\section{Defining Work First and HCD Approaches to Employability}

Many authors have sought to differentiate between Work First and HCD approaches to promoting the employability of those excluded from the labor market (Bruttel \& Sol, 2006; Lindsay et al., 2007; Peck \& Theodore, 2000, 2001; Sol \& Hoogtanders, 2005; Tang \& Cheung, 2007). Lindsay et al. (2007), drawing on previous work by Peck and Theodore (2000) and others, provide a model comparing Work First and HCD that makes distinctions across five dimensions: the rationale for employability programs, their targets (what the policy or program is seeking to achieve for the individual), the intervention model deployed (the content and structure of services to improve employability), how they mediate the relationship between individuals and the labor market, and how employability programs themselves engage with individuals. Table 1 presents an adapted version of Lindsay et al.'s (2007) framework and provides the basis for the following discussion.

\section{INSERT TABLE 1 HERE}




\section{Rationale and "Program Targets" of Work First and HCD}

First, in terms of the rationale and sought outcomes (or program targets) associated with the two models, there are clear differences. By definition, the prioritization of an immediate return to work is fundamental to the Work First approach. In terms of targets, Work First programs place "an emphasis on job seekers, wherever possible, moving quickly towards any kind of work" (Lindsay, 2010, p. 126). The stated aims of such programs often explicitly focus on "immediate labor market entry" (Mitchell et al., 2007, p. 294), prioritizing "labor market attachment on the premise that any job is better than none" (Mead, 2003, p. 442) and emphasizing the negative consequences of individuals experiencing prolonged periods without work.

The rationale for Work First is therefore closely related to "hysteresis" theories in labor economics. These theories posit that "duration dependency" (the increased likelihood of continued exclusion among the long-term unemployed due to the deterioration of skills and work habits) is important in explaining high levels of structural unemployment (see, for example, Layard, 2000). The logical conclusion of such a position is that employability programs should seek to move people into the regular labor market as quickly as possible in order to limit unemployment duration. As Lindsay (2010, p. 124) notes, such thinking has informed a number of supply-side employability policies, "from keeping benefit replacement rates relatively low to increasing compulsion upon the unemployed to re-engage in the labor market, for example through Work First activation." Accordingly, an important challenge to the rationale for Work First models is that there seems to be evidence that labor demand fluctuations are more powerful in explaining long-term unemployment rises than is duration dependency and hysteresis. Webster (2005) has shown that changes in long-term unemployment in the United Kingdom largely mirror trends in general rates of worklessness (once time lags are accounted for), suggesting that 
high long-term unemployment is more a function of labor market weaknesses than the declining skills and aspirations of the unemployed.

Among some US social theorists in particular, an alternative theoretical foundation to justify Work First programs is found in the "dependency culture" or "underclass" thesis, whereby a demoralized and demotivated workless class is seen as making conscious choices to avoid job opportunities (Mead, 2003). Evidence for these claims has proved elusive, as people excluded from the labor market consistently report similar attitudes and aspirations to those in work (Beatty et al., 2010; Fletcher, 2007). This would explain why, in times of economic recovery, many alleged underclass members make their way back into work, having been given the opportunity to do so by expanding labor market demand (Freeman, 2000). Nor has the underclass thesis been able to explain why regions and localities that have hemorrhaged jobs during periods of industrial restructuring continue to report high levels of worklessness when compared with more economically resilient neighboring labor markets. For Ritchie et al. (2005, p. 43) "these understandings of an underclass caused by individual and behavioral problems fail to take into account the structural causes of worklessness"; but it is clear that accounts of unemployment focusing on the individual continue to inform Work First responses that seek to press job seekers into employment through a mix of "carrots and sticks" (Castonguay, 2009).

The rationale and targets for HCD-oriented approaches tend to be quite different. Of course, there remains a focus on getting unemployed people back to work, but HCD models arguably deemphasize immediate labor market integration, instead prioritizing the development of skills that will enable people to find suitable employment (Hagelund \& Kavli, 2009). Accordingly, "HCD approaches are distinguished by the rationale that job seekers will often require substantial support (potentially over a prolonged period) in order to improve their long- 
term employability (with the implication that this will require substantial investments in the education, skills and health of individuals)" (Lindsay et al., 2007, p. 541). Program targets are less concerned with the immediate placement of clients into any job and more focused on sustainable transitions and progression through education as well as pre-work and in-work training. Central to the HCD model is the idea that substantial gains in employability and skills, placed alongside support for the establishment of continuing development and progression routes at work, can solve the problem of "revolving door" participation in employability programs, whereby lower-skilled people tend to cycle between periods of unemployment, Work First programs, and temporary, low-quality jobs (Peck \& Theodore, 2000).

\section{"Intervention Models"}

Work First and HCD approaches also differ significantly in their content or intervention models. It has been noted that job-search assistance/job matching is central to the content of Work First (Ochel, 2005) and in some cases is the only provision offered under these programs (Bruttel \& Sol, 2006). Under Work First, the prioritization of job matching is key to facilitating the immediate returns to work that define the program targets for such initiatives (see above). Policymakers opting for Work First may also be hoping to tap a potential "deterrence effect," whereby the threat of immediate, extensive, compulsory job-search activity is meant to discourage unemployed people from claiming benefits in the first place (Daguerre \& Etherington, 2009). Some Work First providers would argue that their programs might also include training, but in most cases these activities tend to be short-term, with a focus on improving the individual's motivation and generic skills (Daguerre, 2007). In summary, Sol and Hoogtanders (2005, p. 147) have provided what is often cited as a standard definition of Work First: 
Work First programs seek to move people out of welfare and into unsubsidized jobs as quickly as possible, and job search itself is a central activity in these programs.... For those who fail to get a job straight away, Work First provides additional activities directed at addressing those factors impeding employment. These activities might include education, training and work experience. In the context of Work First, they generally are short-term, closely monitored and either combined with or immediately followed by additional job search.... In addition, Work First uses sanctions as a main component in its approach, rather than trust. Some analysts have consistently suggested that a feature of Work First programs is the manner in which they restrict access to human capital development for participants (Deprez \& Butler, 2007). As Goldrick-Rab and Shaw (2005, p. 293) note with reference to US welfare reforms: "Work First emphasizes rapid job placement as the strategy of choice in achieving stable employment and moving out of poverty. As such, it cements a gradual movement away from the human capital philosophy that ... emphasizes skills and education as the most effective long-term path to economic self-sufficiency." Ridzi (2009, p. 10) agrees that the US model of Work First activation "de-emphasizes education, training and even career advancement under the pretext that motivating people to take any job they can will jumpstart the long and arduous process of climbing the career ladder from the very bottom up."

An archetypal skills-based, HCD-oriented approach suggests a different intervention model. Here, the aim is to facilitate the development of skills and attributes that will equip people to find and retain suitable jobs and advance through in-work progression routes (Peck \& Theodore, 2001). Its intervention model therefore requires strong links to well-funded skillsfocused employability services (including, if necessary, long-term education and training). Skills 
development opportunities may be linked to extensive accreditation (Hagelund \& Kavli, 2009). Lindsay et al. (2007) suggest that HCD approaches also tend to better integrate employability and training provision with a range of other holistic services addressing the full range of barriers to work faced by job seekers (for example, health problems, substance dependency, or complex caring responsibilities). The HCD intervention model requires the use of professionals—such as "personal advisers" (PAs) or case managers - capable of working with clients in a holistic way to improve their employability and empowered to direct them to appropriate learning and development opportunities (Lødemel \& Trickey, 2001). It is again important to note that PA services are also a key element of Work First interventions; but, as Mazzeo et al. (2003) argue with reference to US welfare reform measures, even when intensive adviser assistance is offered under such programs, there remains a strong emphasis on immediate, compulsory, work-based activity as the outcome being sought for the unemployed.

\section{Relationship to the Labor Market}

Another distinctive feature of the Work First model is that it seeks to respond to, rather than adapt, existing labor market opportunities. The assumption is that employability programs should be demand-responsive, placing job seekers into opportunities that already exist in the "regular" labor market. As shown below, this means that Work First approaches tend to run into trouble in labor markets where demand is weak and perform more poorly during eras of economic crisis. Work First therefore assumes that the sole role of the employer is to provide a job opportunity; it is the responsibility of the individual (perhaps assisted by an employability program) to offer the skills required by the employer (Ray et al., 2009). Another consistent theme in how Work First programs connect with the labor market relates to the downplaying of concerns with the quality and sustainability of job outcomes. There tends to be a focus on "quick re-entry in the labor 
market regardless of the quality of employment" (Daguerre \& Etherington, 2009, p. 11). As Handler (2006, p. 119) notes, referring to the US context: “A Work First strategy . . encourages recipients to take any job, even a low-wage entry-level job.”

Conversely, HCD approaches focus on achieving high-quality, sustainable outcomes, prioritizing measures to promote continuous skills development and in-work progression (Lindsay et al., 2007). HCD models might therefore involve the establishment of "intermediate labor markets"-that is, a subsidized and/or supported employment environment where more disadvantaged program participants can make gradual progress in developing skills and integrating into a workplace environment, equipping them to make the transition to work in the "real” economy (Gregg, 2009). HCD approaches might also involve partnership between employability program providers and employers to ensure that participants entering work are given the support needed to sustain transitions and to identify opportunities for progression and in-work training (Ray et al., 2009). It is notable that national activation regimes where social partnership structures inform the development of employability programs (for example, through advisory councils bringing together employers, trade unions, and policymakers in countries like Denmark) appear more often to report HCD-oriented interventions characterized by substantial investment in vocational training and in-work support (Serrano Pascual \& Magnusson, 2007). At a most basic level, HCD-oriented employability programs are more likely to seek to match participants to workplaces and job roles to which they are suited and where there is some opportunity for personal development and advancement, disputing the Work First assumption that "the aim is not to establish a long-term career goal but to reinforce the belief that any job is a first career step, no matter how precarious this employment might be" (Sol \& Hoogtanders, 2005, p. 147). 


\section{Relationship with Individuals}

A final defining feature of Work First approaches to employability relates to their far more dirigiste relationship with individual program participants. Work First is informed by an understanding of labor market exclusion that sees behavioral and attitudinal failings as key, so that behavior-shaping incentives and punitive measures are required. Accordingly, compulsory work-related activity is enforced by the threat of sanctions that can be applied to welfare benefits. For Daguerre (2007, p. 5), under Work First, “welfare claimants are faced with sanctions if they do not comply with work requirements and do not develop the 'right' attitude to employment." At one extreme, Work First can be equated with workfare (as practiced in the United States and some other countries) — programs that mandate unpaid work activities in return for benefits or other forms of financial support (Crisp \& Fletcher, 2008). Under many other compulsory Work First models, "non-compliance with work requirements can lead to substantial benefit sanctions, if not blanket denial of benefit entitlement" (Daguerre \& Etherington, 2009, p. 11). Work First approaches therefore tend to be accompanied by generally greater conditionality and less generosity in the welfare benefits system (i.e., benefits are set at a low level and are more difficult to access) (Daguerre, 2008); but they also place a strong emphasis on in-work incentives, such as tax credits that top up low wages for former program participants (Lindsay, 2010).

Sol and Hoogtanders (2005) suggest that similar levels of compulsion and conditionality are less common in HCD-oriented models, where providers hope that an emphasis on choice and quality in services will negate the need for punitive measures. There are examples of HCDoriented programs that have retained strong elements of compulsion (Hagelund \& Kavli, 2009); but for Dean (2003, p. 442), the human capital approach "is characteristically (but not 
necessarily) predicated on voluntary participation." Trust, rather than coercion, is the basis of relationships that employability program providers seek to build with participants (Lødemel \& Trickey, 2001). The assumption is that job seekers will respond positively to the opportunity to choose an appropriate skills development or work experience intervention, so that in many cases financial threats or incentives will be unnecessary. Finally, the greater emphasis on choice and voluntarism that generally defines HCD-oriented approaches means that they may be better placed to help job seekers to cope with non-work-related issues while participating in employability programs. As noted above, Work First is generally more associated with imposing activity on program participants — as Carpenter et al. (2007, p. 164) note, "people's life goals may at times conflict with a Work First strategy"-whereas there may be more scope to cope with (for example) caring roles or health problems under voluntary HCD-oriented programs.

It is of course important to reiterate that the Work First and HCD-oriented approaches discussed above are ideal types and that most actual employability programs will exhibit elements of both models. As Dean (2009, p. 110) notes in his comparison of Work First and HCD concepts, "welfare-to-work regimes are invariably hybrid in nature, reflecting contested discourses of responsibility and the inherent instability of the ethical foundations of welfare." Dean (2009, p. 110) notes that the US welfare reform agenda "is generally held to exemplify the Work First approach, [but] initiatives taken in certain states under the Workforce Investment Act of 1998 provide isolated examples of a human capital approach." Similarly, Lindsay et al. (2007) see the United Kingdom's recent welfare-to-work programs as a hybrid, with some HCD elements surviving within an increasingly Work First-dominated agenda. Riach \& Loretto (2009, p. 104) share this analysis of UK policy as "characterized by a Work First tactic," but 
with something of "an HCD orientation [that theoretically] will benefit people with multiple disadvantages."

While most employability interventions will fall into a hybrid category, there is a general consensus that liberal welfare states (such as the United Kingdom and United States) tend to offer the most Work First-oriented programs, while some social democratic welfare states (such as Sweden) are perhaps at the opposite end of the spectrum, emphasizing training and HCD (Daguerre, 2008; Dean, 2009). However, since the 1990s, there has arguably been a shift towards more Work First-oriented approaches in many developed nations, irrespective of welfare regime traditions. Across many states belonging to the Organisation for Economic Co-operation and Development (OECD), "the Work First attitude has penetrated public institutions, with the public employment service often quickly matching clients to available jobs, as opposed to helping them invest in their human resources and skills and move towards more sustainable long-term careers" (Froy \& Giguere, 2010, p. 27).

Given this context, and the evidence that these two models are a useful starting point for discussing the rationale and content of employability programs, an obvious next issue is to discuss the evidence on what types of intervention work best under what circumstances and the appropriateness of Work First and HCD strategies in responding to the post-2008 crisis and accompanying high levels of worklessness.

\section{What Works? Work First Versus HCD}

In terms of achieving immediate (if sometimes temporary) reductions in welfare rolls, Work First strategies have been seen as more effective than HCD-oriented models. Layard (2004, p. 5) argues that the evidence supports "Work First over training first" as a means of promoting immediate transitions off welfare benefits. Advocates of Work First point to the reduced welfare 
rolls that often follow a tightening of welfare eligibility requirements and increased compulsion and conditionality. Evidence reviews of the impact of active labor market policies (ALMPs) have produced mixed results but tend to be more positive toward Work First interventions. De Koning (2007) provides a descriptive report of the results of 130 evaluation studies, concluding that there is strong evidence of positive effects from a combination of sanctions and financial incentives, while training programs have a more mixed record. Kluwe (2006), using probit modeling to provide a meta-analysis of 137 “observations” (i.e., quantifiable evaluation outcomes) from 95 different studies of employability programs, concludes that the impact of training programs was positive but modest, whereas "services and sanctions" showed significantly better performance. Accordingly, both studies argue that while there are positive employment effects associated with some HCD-oriented programs, the classic measures associated with Work First—-sanctions and intensified job search—are most effective in quickly reducing welfare rolls. Given that such Work First measures are also inevitably cheap to implement, they may also be considered more cost-effective in the short term (Daguerre \& Etherington, 2009). Indeed, as noted above, there is evidence of deterrence effects associated with increased compulsion and conditionality, so that welfare rolls decline even before the implementation of policy changes (Kvist \& Pedersen, 2007).

Ochel (2005, p. 87) conducted a structured evidence review summarizing 18 evaluation studies of employability programs across five countries, suggesting that those mixing Work First and HCD elements were the best performers but generally confirming "the superiority of Work First programs over human capital investment" in achieving both exits from welfare and job entries. Martin's (2000, p. 93) review of evidence on training initiatives in Canada, Sweden, and the United States focused mainly on the findings of eight large-scale evaluations and found that 
some programs "have yielded low or even negative rates of return for participants when the estimated program effects on earnings or employment are compared with the cost of achieving those effects." Furthermore, HCD models have been criticized as encouraging "lock-in" effects, where unemployed people concentrating on participating in training may pass up opportunities to move into employment. However, Meadows (2006) notes that supposed lock-in effects associated with training in fact often represent the reality that job seekers wish to concentrate on, so that they complete (hopefully) useful training prior to moving toward work. Furthermore, doubts have been cast on claims that Work First approaches are a panacea for the problems of worklessness. First, while we might expect that rule changes limiting access to benefits and increasing compulsion will result in fewer claimants, it is not clear that such measures improve employability or chances of exiting benefits to employment (see, for example, Manning, 2009). And when Work First participants do enter employment, many evaluations have concluded that the same people would have found work anyway. Evaluations of ALMPs targeting a range of workless claimants in the United Kingdom — from young people to those with health problemshave identified significant "deadweight" effects (where the same person, or another member of the targeted group, would have found a job even in the absence of ALMP), indicating that the additional job impacts of such programs were limited (Blundell et al., 2003; National Audit Office, 2010; Van Reenen, 2004).

It also appears that time frame matters in evaluating the benefits of Work First- and HCD-oriented approaches. Gaps in longitudinal data represent a major problem in assessing the extent to which Work First and HCD offer long-term benefits, so that former participants are able to retain employment and progress in the workplace. However, there is some evidence that HCD initiatives continue to amortize (or provide a return on) human capital investments in the 
long run (Green \& Hasluck, 2009). For example, Meager (2009) points to evidence from the small number of evaluations in Sweden, the United Kingdom, the United States, and elsewhere that have sought to follow training participants for more than a year after the completion of programs; he argues that there appears to be a "slow burn" impact of some investments in human capital that may continue to add to participants' employability over a prolonged period. Indeed, some studies of HCD programs have found little by way of job impact in the short term but significant positive effects in the long term. Positive long-term impacts of training-focused employability programs were reported in the 1990s in both the United Kingdom (Payne et al., 1996) and the United States (Hotz et al., 2006). Card et al.'s (2010) meta-analysis of more than 90 evaluations across 26 countries found that HCD program impacts were more powerful after two to three years than in the immediate-term with regard to positive employment effects and progression in the labor market reported by completers. Meadows's (2006) review of ALMPs similarly concludes that Work First services have a larger impact for less cost in the short term, while (well-resourced) HCD programs may have better long-term impacts on sustainability and progression:

Over longer periods of time, and particularly over a period of five years or more, the effect of training increases and continues to grow. Moreover, those who have entered employment after a period of training seem to have better rates of job retention than those who have entered from Work First provision, probably because they are better able to match the skill requirements of the jobs they are doing. (Meadows, 2006, p. 25)

The corollary of the failure of some Work First programs to deliver long-term, sustainable outcomes is that participants may find themselves "cycling" between activation 
programs, short-term jobs, and periods of unemployment (Daguerre \& Etherington, 2009). Lindsay (2010, p. 129), reviewing evidence from the United Kingdom's New Deal ALMPs during the 2000s, notes: "While initial job entry figures were encouraging, the New Deal programs soon faced an increasing problem of 'revolving door' participation, with clients moving from activation into short-term employment, and then back into unemployment, eventually repeating their participation in activation." These are potentially serious failings of Work First models (or indeed any other intervention that does not result in participants making sustainable progress in the labor market). It is difficult to square the positive evaluations of Work First programs as being effective at helping people into work with the reality that many "successful completers" will be back on benefits (and possibly again the target for Work First programs) within a year (Finn, 2011). There is also a risk that such employability programs will fail to offer routes out of poverty and into decent work. There remains a concern that "Work First programs are pitched in such a way that ... interventions are far too brief and modest in scope to allow participants an opportunity to move into stable, high-quality jobs" (Peck \& Theodore 2000, p. 132). As Ridzi (2009, p. 10) notes in examining US Work First programs, there is evidence that the lack of training provided can leave "successful" participants "permanently stranded in the low wage labor market."

There are also some concerns that a decisive shift toward Work First approaches to employability may result in deskilling, or at least reinforce processes of polarization in access to skills development that appear to increasingly define labor markets in the United States, United Kingdom, and beyond (Autor, 2010; Goos et al., 2009). In the United States, some evaluations have pointed to the deskilling effects of Work First programs, which can direct people with potentially valuable and transferable skills toward short-term, basic activation programs of little 
relevance to their needs. Participants have reported a "degradation of their intellect and technical abilities" as a result of mandatory participation in such programs (Gingrich, 2008, p. 388).

Clearly there is a danger of a much more serious "lock-in" effect here, whereby participants in employability program are forced to undertake compulsory work of limited value rather than refreshing and applying existing skill sets. Certainly, large groups of low-wage employees in welfare states such as the United Kingdom report that they are unable to utilize their existing skills at work (Wright \& Sissons, 2012), suggesting that Work First may be feeding the unemployed into unproductive positions characterized by underemployment and few opportunities for progression. This is an inefficient use of both human capital and public money. Furthermore, given the evidence that underemployment can produce negative socioeconomic and psychological outcomes for those at the bottom end of the labor market (see Virick \& McKeeRyan, this volume) there is a risk that, for some among the unemployed, Work First will do more harm than good.

Finally, both Work First and HCD models to employability assume a "supply side" approach - they seek to improve employment outcomes by intervening at the individual level, so that job seekers are adapted to better match the demands of employers and the labor market. Where labor demand is weak, such supply-side models will run into trouble. As Macnicol (2008, p. 592) notes, “improving employability does not by itself create jobs.” This is particularly problematic for Work First programs, which are based on the assumption that there are accessible entry-level jobs into which the unemployed can be quickly placed. Yet there is substantial evidence to suggest that the impact of Work First programs is shaped by local labor market demand. For example, McVicar and Podivinsky (2009) and others have shown that the impact of New Deal employability programs has varied significantly across regions of the United 
Kingdom. In areas where mass job losses followed from the decline of traditional industries in the 1980s and 1990s and where economic regeneration remains incomplete, the performance of such programs has been least effective (Lindsay, 2010). North et al. (2009, p. 1038) criticize the "long-term neglect of demand-side issues" within the employability policy agenda in the United Kingdom (and some other OECD states), which largely fails to address issues around the amount and quality of work available; in particular, "Work First approaches remain constrained by the fact that, for many disadvantaged in the labor market and living in areas of concentrated worklessness, the low-paid entry-level jobs on offer provide few prospects for developing skills and moving out of poverty" (North et al., 2009, p. 1037).

It has proved difficult for Work First advocates to engage with these criticisms, because demand-side barriers to employment do not square with assumptions behind the Work First model: content (with its strong focus on job search), understanding of the labor market (which sees employers as the end recipients of employable candidates rather than proactive partners in providing appropriate opportunities), or approach to dealing with individuals (which relies on behavioral incentives and sanctions to "encourage" people into work). In an attempt to "individualize a collective problem" (Lindsay, 2007), it assumes that the problem of unemployment is a problem of the unemployed. Yet as Peck (1999) notes, it seems fanciful to argue that, for example, unemployment is five times higher in some of the United Kingdom's postindustrial areas than in wealthy suburbs, where opportunities are plentiful, because of a shared "local deficiency in the work ethic" in the former communities: "It is a straightforward reflection of job availability. In depressed areas, even the most active of active welfare-to-work policies will struggle to achieve results in the face of a shortage of jobs" (Peck, 1999, p. 357). 
As noted above, to some extent the same critique can be directed at HCD-oriented employability programs, which similarly focus their resources on the individual, sometimes with little sense of connection to the level or characteristics of job demand in local labor markets. However, advocates of $\mathrm{HCD}$ can at least point to a rationale and intervention model that emphasize long-term employability benefits and transferable skills. Accordingly, even if HCD programs fail to help unemployed people move into work in the immediate term because of weak labor markets, they might be more likely to deliver skills that are applicable within future workplace contexts. In comparison, Work First programs often have little by way of skills content; in the context of the 2008-2009 recession and continuing economic crisis, they are likely to try to force some job seekers into opportunities that simply do not exist. The result may be that vulnerable workless people are forced off benefits as a result of a tightening of eligibility and conditionality while not being offered sustainable progression routes from welfare to work. A strengthening of Work First during the ongoing economic crisis may mean fewer people in the welfare benefits system, but "they may not be in employment either" (Lindsay \& Houston, 2011, p. 714). Given the fragility of many local, regional, and national labor markets in an era of prolonged economic crisis, the rationale and added value of Work First programs (which are based on an assumption of healthy labor demand) is questionable. Even the OECD — previously a strong advocate of Work First — argues that "it is advisable to shift from a 'Work First' approach to active labor market policy to a 'Train First' approach for those at high risk of long-term unemployment in the context of the downturn" (Froy \& Giguere, 2010, p. 13).

The discussion above highlights how the evaluation of Work First- and HCD-oriented approaches to employability remains contested territory. A number of reviews of evaluation evidence have pointed to the apparent superiority in immediate outcomes delivered by Work 
First employability programs while criticizing potential lock-in effects associated with HCDoriented training (i.e., in line with their core objectives, Work First programs get people into paid employment more quickly). However, the research question informing such studies appears somewhat "loaded"; by definition, programs aiming to facilitate immediate job entry at all costs are more likely to report these outcomes than initiatives seeking to enhance human capital and provide more gradual (but perhaps also more sustainable) transitions to work. There is evidence that deterrence effects and compulsory job-search activities mean that Work First programs can push people off benefits and into work more quickly than would otherwise have happened. But for Work First to work, such programs need the right kind of participants (ideally those relatively close to the labor market and with fewer disadvantages) and the right kind of economic conditions (where there are ample entry-level job opportunities). We have also seen above that HCD-oriented training interventions may offer important routes into work for hard-to-reach groups as well as longer-term benefits for participants who can develop transferable skills that can lead to higher-quality employment.

\section{Conclusions}

Policymakers across the OECD and beyond are concerned to develop interventions that enhance the employability of unemployed and inactive groups and provide routes into work. Comparing Work First and HCD models of employability allows us to consider how the different rationales and content of ALMPs can shape how they connect with individuals and the labor market and the outcomes achieved for participants. As noted above, most ALMP regimes will be something of a hybrid combining elements of Work First and HCD (Castonguay, 2009). However, this chapter has noted that distinctive aims and approaches associated with specific employability programs can be identified as being more Work First- or HCD-oriented. This matters, because of the 
different outcomes (contingent on individual characteristics and labor market conditions) that tend to be reported by these different kinds of programs and because the balance between Work First and HCD within employability programs continues to shift. Indeed, there is some evidence to suggest that the Work First model has enjoyed a position of increasing dominance in the United States, United Kingdom, and many other OECD countries (Froy \& Giguere, 2010). Even those employability-focused programs that target hard-to-reach groups some distance from the labor market tend to be judged against job-entry targets (Castonguay, 2009). Policymakers faced with spiraling unemployment and shrinking budgets for public services may be increasingly tempted to pursue the cheaper option of Work First-oriented employability programs (Driver, 2009).

The evidence suggests that if the best results are to be achieved, a degree of balance will be required between Work First and HCD within employability programs. In the short term, Work First measures can help direct those unemployed people who are close to being job ready toward opportunities in buoyant labor markets (Daguerre \& Etherington, 2009). On the other hand, where Work First is applied to job seekers facing multiple and complex barriers to employment, the evidence suggests that it is unlikely to produce sustainable positive outcomes and at best will result in driving people off welfare without work or into patterns of cycling between low-quality jobs and unemployment. In short, "Work First activation, which focuses on increasing motivation, generic skills and job-search effort, is not equal to the task of addressing the range of barriers faced by the most disadvantaged" (Lindsay, 2010, p. 139). Indeed, none of the narrowly focused policy evaluations discussed above deal with the potential broader social costs of Work First programs that seek to push people off benefits and into low-paid jobs. For those denied access to benefits (for example, as a result of falling foul of Work First sanctions) 
and indeed those trying to cope with the transition to entry-level, low-wage work, there may be increased risks of poverty. The social cost of poverty and inequality is a matter of considerable debate and beyond the scope of this chapter, but there is evidence to suggest that experiences of poverty feed into pressures on health, social work, and criminal justice budgets (Wilkinson \& Pickett, 2009). At the very least, Work First approaches must be complemented by more HCDoriented training and personal development for those who need more intensive support if they are to be assisted toward sustained, good-quality job outcomes. Yet for some analysts, Work First is synonymous with, indeed facilitates, polarized labor markets that offer few routes out of poverty for those at the bottom (Peck \& Theodore, 2000).

More generally, both Work First and HCD elements of employability programs will work better if they are integrated with policies to promote more and better jobs in depressed labor markets and strategies to encourage employers to provide sustainable progression routes and training in the workplace. The latter workplace strategies are important if job seekers are to avoid the "revolving door" of participation in employability programs followed by temporary jobs without prospects, followed by unemployment, and then repeated participation in employability programs. The former policies to stimulate job growth are even more essential, because in an era of economic crisis, supply-side employability programs will inevitably run up against the problem of limited labor demand. There must be a coherent attempt to link the demand and supply sides of the employability equation so that we no longer "individualize the collective problem" of unemployment (McQuaid \& Lindsay, 2005). Only by taking meaningful action to stimulate job growth - especially in those regions and localities hit hardest by recession and economic crisis - will policymakers ensure that those targeted by Work First programs will be able to move into the promised "unsubsidized jobs as quickly as possible" (Sol \& Hoogtanders, 
2005, p. 14), or that those benefitting from human capital development initiatives will be able to deploy their new skills within decent jobs, with opportunities for progression.

Our collective complicity in "individualizing" the problem of unemployment has legitimated a policy agenda that seeks to shift responsibility from the state to the individual victim of job loss. Yet we know from previous economic crises that "unemployment has to be examined as a characteristic of the society in which we live, not just of those members of it who happen to be out of work at any one time" (Sinfield, 1981, p. 122). There is a fundamental need to reconnect with the idea of collective solutions to unemployment that identify active roles for employers and policymakers in providing opportunity as well as the responsibilities of the individual to take up opportunities to work and/or train (Lindsay, 2010).

\section{Future Directions}

A number of research questions remain open. There is broad agreement on the need for a combination of Work First- and HCD-oriented approaches to employability, depending on individuals' barriers to employment and the labor market context (Castonguay, 2009; Daguerre \& Etherington, 2009). However, as noted above, there remains considerable debate on what combination of policies works best in which circumstances. There is a need for further comparative and (crucially) longitudinal research to measure the impacts of different combinations of policies over time, across different labor markets, and on specific client groups. As noted above, the small number of studies that have sought to capture the long-term progression of participants after ALMP participation have challenged the assumed superiority of Work First interventions, identifying "slow burn" benefits from HCD. There is a need for much more longitudinal research on these issues. Much of the research agenda on employability programs also starts from the assumption that initiatives will either succeed or fail in delivering 
predicted positive outcomes; yet we have seen above that there may be negative consequences associated with different models of employability provision (ranging from lock-in effects associated with some training interventions to an increased risk of poverty and exclusion from the application of sanctions or as a result of forcing individuals to accept low-paid work). There is a need to broaden the research agenda to assess all the costs and benefits associated with Work First and HCD approaches to promoting employability, especially from the perspective of program participants.

At the level of the individual, there is a need to deploy multidimensional models for understanding and assessing employability (see McQuaid \& Lindsay, 2005, for discussion) that capture a range of personal characteristics and barriers, so that we can match unemployed people to programs more effectively. Such models and assessment tools must engage with the full range of individual barriers, personal circumstances and external (including labor market) factors that shape employability trajectories. There may also be benefits in capturing psychological data (such as measures of individual coping strategies) in order to gain a better understanding of which interventions might work best for ALMP participants. Andersen's (2011) research with Danish ALMP completers has identified potential relationships between individuals' different coping strategies and the effects of employability interventions, concluding that such psychological measures should be used by PAs to ensure that the unemployed are directed toward appropriate programs. There is scope for further research on how coping strategies and other individual traits shape the outcomes achieved by ALMP participants in order to inform the personalization of services to the needs and characteristics of unemployed people.

Finally, as emphasized throughout this chapter, debates on employability policy remain too narrowly focused on the supply side of the labor market. The outcomes achieved by 
participants in both Work First- and HCD-oriented employability programs are contingent on a number of broader factors, including the extent and nature of local labor demand, the sustainability and quality of job opportunities, and the support provided by employers. If policy researchers are to inform this debate, they must adopt a broad-based and holistic approach to the study of employability—one that helps policymakers to grapple with the combination of individual, social, workplace, and labor market problems that are at the heart of the ongoing unemployment crisis in many communities. And if policymakers are to achieve their aim of helping unemployed people move from welfare to work, there must be a renewed commitment to addressing the full range of barriers that leave some people excluded from the world of work for prolonged periods. There must also be a thorough, critical assessment of the long-term benefits of both Work First and HCD interventions for individuals and economies. For example, future evaluations need to tackle directly the critique of Peck (1999) and others that Work First ALMPs do little more than facilitate (if necessary by compulsion) the churning of the low-skilled between low-wage jobs at the bottom of the labor market, with few participants permanently escaping the risk of recurring unemployment or poverty.

\section{Key Points}

- $\quad$ Both Work First and HCD programs play an important role in ALMPs designed to improve the employability of unemployed people. But in many OECD states, Work First programs have come to be seen as more cost-effective and play an increasingly prominent role.

- A number of evaluations have pointed to the cost-effectiveness of Work First programs in producing quicker job entries. While there is mixed evidence as to the effectiveness of $\mathrm{HCD}$, concerns have been raised that long-term human 
capital-oriented programs can produce "lock-in" effects, thus discouraging job seekers from taking up employment opportunities.

- However, this chapter has pointed to the need for more extensive research and evaluation before selecting Work First-- and/or HCD-oriented employability programs. There is a need to consider the potential negative impacts of programs (for example, the socioeconomic and psychological effects on Work First participants who may find themselves churning between repeated periods of unemployment, ALMP participation, and insecure low-paid work). There is also a need to consider the long-term benefits of all programs, and especially HCDoriented interventions, that may amortize investments in individuals' skills and employability over a longer time period.

- In order to evaluate effectively both Work First and HCD approaches, policymakers need to adopt a broad-based understanding of employability, which reflects how individual (including psychological) characteristics, personal circumstances, and external factors - such as the quality and quantity of jobs available—shape people's trajectories in the labor market.

\section{References}

Andersen, S. H. (2011). Exiting unemployment: How do program effects depend on individual coping strategies? Journal of Economic Psychology, 32(2), 248-258.

Autor, D. (2010). The polarization of job opportunities in the US job market. Washington DC: Center for American Progress.

Beatty, C., Fothergill, S., Houston, D., Powell, R., \& Sissons, P. (2010). Bringing incapacity benefit numbers down: To what extent do women need a different approach? Policy Studies, 31(2), 143-162.

Blundell, R., Reed, H., Van Reenen, J., \& Shephard, A. (2003). The impact of the New Deal for Young People on the labour market: A four year assessment. In R. Dickens, P. Gregg, \& J. Wadsworth (Eds.), The labour market under New Labour: The state of working Britain (pp. 17-31). Basingstoke: Palgrave.

Bruttel, O., \& Sol, E. (2006). Work First as a European model? Evidence from Germany and the Netherlands. Policy and Politics, 34(1), 69-89.

Card, D., Kluwe, J., \& Weber, A. (2010). Active labour market policy evaluations: A meta-analysis. Economic Journal, 120, F452-F477. 
Carpenter, M., Freda, B., \& Speeden, S. (2007). Beyond the workfare state: Labour markets, equalities and human rights. Bristol, UK: Policy Press.

Castonguay, J. (2009). Benchmarking carrots and sticks: Developing a model for the evaluation of work-based employment programs. Amsterdam: University of Amsterdam.

Crisp, R., \& Fletcher, D. (2008). A comparative review of workfare programs in the United States, Canada and Australia. London: Department for Work and Pensions.

Daguerre, A. (2007). Active labour market policies and welfare reform. Basingstoke, UK: Palgrave.

Daguerre, A. (2008). The second phase of US welfare reform, 2000-2006: Blaming the poor again? Social Policy and Administration, 42(4), 362-378.

Daguerre, A., \& Etherington, D. (2009). Active labour market policies in international context: What works best? Lessons for the UK. Norwich, UK: Stationery Office.

De Koning, J. (2007). The evaluation of active labour market policies: Measures, public-private partnership and benchmarking. Aldershot, UK: Edward Elgar.

Dean, H. (2003). Re-conceptualising welfare-to-work for people with multiple problems and needs. Journal of Social Policy, 32(4), 441-459

Dean, H. (2009). The ethics of welfare-to-work. In K. Schneider \& H. Otto (Eds.), From employability towards capability (pp. 97-116). Luxembourg: Inter-Actions.

Deprez, L., \& Butler, S. (2007). The capability approach and women's economic security: Access to higher education under welfare reform. In M. Walker \& E. Unterhalter (Eds.), Amartya Sen's capability approach and social justice in education. New York: Palgrave.

Driver, S. (2009). Work to be done? Welfare reform from Blair to Brown. Policy Studies, 30(1), 69-84.

Finn, D. (2011). Welfare to work after the recession: from the New Deals to the Work Programme. In C. Holden, M. Kilkey, \& G. Ramia (Eds.), Social Policy Review 23 (pp. 127-145). Bristol, UK: Policy Press.

Fletcher, D. R. (2007). A culture of worklessness? Historical insights from the Manor and Park area of Sheffield. Policy and Politics, 35(1), 65-85.

Freeman, R. (2000). The US underclass in a booming economy. World Economics, 1(2), 89-100.

Froy, F., \& Giguere, S. (2010). Putting in place jobs that last. Paris: OECD.

Gingrich, L. G. (2008). Social exclusion and double jeopardy: The management of lone mothers in the market-state social field. Social Policy and Administration, 42(4), 379-395.

Goldrick-Rab, S., \& Shaw, K. (2005). Racial and ethnic differences in the impact of Work-First reforms on access to postsecondary education. Educational Evaluation and Policy Analysis, 27(4), 291-307.

Goos, M., Manning, A., \& Salomons, A. (2009). Job polarisation in Europe. American Economic Review Papers and Proceedings, 99(2), 58-63.

Green A. E., \& Hasluck, C. (2009). Action to reduce worklessness: What works? Local Economy, 24(1), 73-82.

Gregg, P. (2009). Job guarantees: Easing the pain of long-term unemployment. Public Policy Research, 16(3), 174179.

Hagelund, A., \& Kavli, H. (2009). In work is out of sight: Activation and citizenship for new refugees. Journal of European Social Policy, 19(3), 259-270.

Handler, J. (2006). Ending welfare as we know it: Welfare reform in the US. In P. Henman \& M. Fenger (Eds.), Administering welfare reform: International transformations in welfare governance (pp. 117-136). Bristol, UK: Policy Press.

Hotz, J., Imbens, G., \& Klerman, J. (2006). Evaluating the differential effects of alternative welfare-to-work training components: A re-analysis of the California GAIN program. Journal of Labor Economics, 24(3), 521-566.

Kluwe, J. (2006). The effectiveness of European active labor market policy. Bonn: Institute for the Study of Labor.

Kvist, J., \& Pedersen, L. (2007). Danish activation policies. National Institute Economic Review, 202, 99-112.

Layard, R. (2000). Welfare-to-work and the New Deal. World Economics, 1(2), $29-39$.

Layard, R. (2003). Happiness: Has social science a clue? Lionel Robbins Memorial Lecture 3. London: Centre for Economic Performance.

Layard, R. (2004). Good jobs and bad jobs. London: Centre for Economic Performance.

Lindsay, C. (2007). The United Kingdom's "Work First" welfare state and activation regimes in Europe. In A. Serrano Pascual \& L. Magnusson (Eds.), Reshaping welfare states and activation regimes in Europe (pp. 35-70). Brussels: Peter Lang.

Lindsay, C. (2010). Re-connecting with "what unemployment means": Employability, the experience of unemployment and priorities for policy in an era of crisis. In I. Greener, C. Holden, \& M. Kilkey (Eds.), Social Policy Review 22 (pp. 121-147). Bristol, UK: Policy Press. 
Lindsay, C., \& Houston, D. (2011). Fit for purpose? Welfare reform and challenges for health and labour market policy in the UK. Environment and Planning A, 43(3), 703-721.

Lindsay, C., McQuaid, R. W., \& Dutton, M. (2007). New approaches to employability in the UK: combining "Human Capital Development" and "Work First" strategies? Journal of Social Policy, 36(4), 539-560.

Lødemel, I., \& Trickey, H. (2001). An offer you can't refuse: Workfare in international perspective. Bristol, UK: Policy Press.

Macnicol, J. (2008). Older men and work in the 21st century: What can the history of retirement tell us? Journal of Social Policy, 37(4), 579-595.

Manning, A. (2009). You can't always get what you want: The impact of the UK jobseekers' allowance. Labour Economics, 16(3), 230-250.

Martin, J. P. (2000). What works among active labour market policies: Evidence from OECD countries' experiences. OECD Proceedings: Policies Towards Full Employment, 191-219.

Mazzeo, C., Rab, S., \& Eachus, S. (2003). Work-first or work-only: Welfare reform, state policy, and access to postsecondary education. Annals of the American Academy of Political and Social Science, 586, 144-171.

McQuaid, R. W., \& Lindsay, C. (2005). The concept of employability. Urban Studies, 42(2), 197-219.

McVicar, D., \& Podivinsky, J. M. (2009). How well has the New Deal for Young People worked in the UK regions? Scottish Journal of Political Economy, 56(2), 167-195.

Mead, L. M. (2003). Welfare caseload change: An alternative approach. Policy Studies Journal, 3, 163-185.

Meadows, P. (2006). What works with tackling worklessness? London: London Development Agency.

Meager, N. (2009). The role of training and skills development in active labour market policies. International Journal of Training and Development, 13(1), 1-18.

Mitchell, A., Lightman, E., \& Herd, D. (2007). Work-first and immigrants in Toronto. Social Policy and Society, 6(3), 293-307.

National Audit Office (2010). Support to incapacity benefit claimants through Pathways to Work. London: National Audit Office.

North, D., Syrett, S., \& Etherington, D. (2009). Tackling concentrated worklessness: Integrating governance and policy across and within spatial scales. Environment and Planning C: Government and Policy, 27(6), 1022-1039.

Ochel, W. (2005). Welfare-to-work experiences with specific work-first programmes in 23 selected countries. International Social Security Review, 58(4), 67-93.

Payne, J., Casey, B., Payne, C., \& Connolly, S. (1996). Long-term unemployment individual risk factors and outcomes. London: Policy Studies Institute.

Peck, J. (1999). New labourers? Making a New Deal for the workless class. Environment and Planning C: Government and Policy, 17(3), 345-372.

Peck, J., \& Theodore, N. (2000). Beyond employability. Cambridge Journal of Economics, 24 (6), 729-749.

Peck, J., \& Theodore, N. (2001). Exporting workfare/importing welfare-to-work: Exploring the politics of third way policy transfer. Political Geography, 20(4), 427-460.

Ray, K., Hoggart, L., Taylor, R., Vegeris, S., \& Campbell-Barr, V. (2009). Rewarding responsibility? Long-term unemployed men and the welfare-to-work agenda. Environment and Planning C: Government and Policy, 27(6), 975-990.

Riach, K., \& Loretto, W. (2009). Identity work and the "unemployed" worker: Age, disability and the lived experience of the older unemployed. Work Employment and Society, 23(1), 102-119.

Ridzi, F. (2009). Selling welfare reform: Work-First and the new common sense of employment. New York: New York University Press.

Ritchie, H., Casebourne, J., \& Rick, J. (2005). Understanding workless people and communities, DWP Research Report 255. Leeds, UK: Corporate Document Services.

Serrano Pascual, A., \& Magnusson, L. (2007). Reshaping welfare states and activation regimes in Europe. Brussels: Peter Lang.

Sinfield, A. (1981). Unemployment in an unequal society. In B. Showler \& A. Sinfield (Eds.), The workless state (pp. 122-166). Oxford, UK: Martin Robertson.

Sol, E., \& Hoogtanders, Y. (2005). Steering by contract in the Netherlands: New approaches to labour market integration. In E. Sol \& M. Westerveld (Eds.), Contractualism in employment services (pp. 139-166). The Hague: Kluwer.

Tang, K. L., \& Cheung, C. (2007). Programme effectiveness in activating welfare recipients to work: The case of Hong Kong. Social Policy and Administration, 41(7), 747-767. 
Van Reenen, J. (2004). Active labour market policies and the British New Deal for the young unemployed in context. In R. Blundell, D. Card, \& R. Freeman (Eds.), Seeking a premier economy (pp. 461-496). Chicago: University of Chicago Press.

Webster, D. (2005). Long-term unemployment, the invention of hysteresis and the misdiagnosis of structural unemployment in the UK. Cambridge Journal of Economics, 29(6), 975-995.

Wilkinson, R., \& Pickett, K. (2009). The spirit level: why more equal societies almost always do better. London: Allen Lane.

Wright, J., \& Sissons, P. (2012). The skills dilemma: skills under-utilisation and low-wage work. London: Work Foundation. 


\section{Table 1.}

\section{Features of Work First and Human Capital Development (HCD) programs}

\begin{tabular}{|c|c|c|}
\hline & Work First Approaches & HCD Approaches \\
\hline Rationale & $\begin{array}{l}\text { Facilitating quick return to labor market by job } \\
\text { search and work-focused training }\end{array}$ & $\begin{array}{l}\text { Improving long-term employability through } \\
\text { improved education, skills, health, and personal } \\
\text { development }\end{array}$ \\
\hline Program targets & $\begin{array}{l}\text { Immediate emphasis on job entry; focus on getting } \\
\text { people into work quickly }\end{array}$ & $\begin{array}{l}\text { gSustainable transitions to work at range of skill } \\
\text { levels with progression routes once in work }\end{array}$ \\
\hline Intervention model & $\begin{array}{l}\text { Job search central and constant; short-term } \\
\text { training; focus on immediate activity }\end{array}$ & $\begin{array}{l}\text { Long-term training; integrated with social care, } \\
\text { education, and health } \\
\text { Personal adviser support }\end{array}$ \\
\hline $\begin{array}{l}\text { Relationship to labor } \\
\text { market }\end{array}$ & $\begin{array}{l}\text { Demand-responsive; seeks to insert job seekers } \\
\text { into available opportunities }\end{array}$ & $\begin{array}{l}\text { Up-skills job seeker to expand range of } \\
\text { opportunities; supports progression in workplace }\end{array}$ \\
\hline $\begin{array}{l}\text { Relationship with } \\
\text { individuals }\end{array}$ & $\begin{array}{l}\text { Use of benefit restrictions, sanctions, and/or } \\
\text { financial top-ups to encourage job entry; emphasi } \\
\text { on compulsion }\end{array}$ & $\begin{array}{l}\text { Encourages voluntary participation by } \\
\text { sdemonstrating benefits of high-quality HCD } \\
\text { opportunities; emphasis on trust }\end{array}$ \\
\hline
\end{tabular}

